\title{
PLASMA MODIFICATION OF POLYVINYL ALCOHOL MICROFIBERS TO IMPROVE COHESION WITH CEMENT MATRIX
}

\author{
Jakub Ďureje ${ }^{a, *}$, Zdeněk Prošek $^{a, b}{ }^{\text {, Jan Trejbal }}{ }^{a}$, Pavel Tesárek $^{a}$ \\ ${ }^{a}$ Czech Technical University in Prague, Faculty of Civil Engineering, Thákurova 7, 16629 Prague, \\ Czech Republic \\ ${ }^{b}$ Czech Technical University in Prague, UCEEB, Třinecká 1024, 27343 Buštěhrad, Czech Republic \\ * corresponding author: Jakub.dureje@fsv.cvut.cz
}

\begin{abstract}
The article describes plasma modifications of the surface of polyvinyl alcohol (PVA) microfibers using oxygen and hydrogen plasma in order to improve the properties of the composite material containing modified microfibers, cement and recyclate. Five different modification times 30,60, 120, 240 and 480 seconds were applied. Changes on fiber surface were detected by SEM analysis, packed cell wettability measurement, and weight loss during modification. The selected durations of plasma treatment were chosen to produce test samples on which the modulus of elasticity was continuously measured and then bending and compression tests were performed. The measured values were compared with the reference samples. Oxygen modified fibers behavior is more hydrophilic compare with reference fibers, but hydrogen modified fibres behave more hydrophobic than reference fibers.
\end{abstract}

KEYwords: Plasma fiber modification, fiber surface modification, hydrogen plasma, oxygen plasma, polyvinylalcohol fibers, PVA fibers.

\section{INTRODUCTION}

Cement composite materials are widespread in the construction industry due to their advantageous properties and relatively low cost. Unfortunately, unreinforced cement composites are typical for their low tensile and bending strength, and brittleness [1]. In the field of cement composites, this disadvantage is reduced by using reinforcement. One of the possibilities of reinforcing cement composites is the use of scattered reinforcing fibers. As early as 3500 years ago, dispersed reinforcements in the form of straw to reinforce unburnt bricks were used. The article deals with synthetic fibers that have been used since the early 1990s. Currently, synthetic fibers are among the most commonly used fibers for reinforcing cement composites in practice [2. The cohesion of fibers with cement matrix in fiber-reinforced cement composites has a significant effect on its properties. Fiber-matrix cohesiveness depends on the interfacial transition zone (ITZ) that transfers the tension to fibers [3]. To increase (or reduce) the coherence of the fibers with the matrix, plasma surface modification can be employed. Plasma is referred to as the fourth state of matter. It consists of charged particles - positive ions and negative electrons and neutral particles 44. Plasma fiber modifications process standardly use low-temperature plasma because of low material temperature resistance. Plasma modifies fiber surfaces mechanically as well as chemically. With the increasing time of plasma modification process, changes on the surfaces are more significant [5], [6]. As reported in many studies, carbon fibers have been successfully modified for application into epoxy binders and polyetherimide (PEI) composites [7], [8]. Polypropylene fibers have been modified by plasma to apply colors and adhesives to their surface 9]. Plasma modification has successfully increased the resistance of sisal fibers in alkaline environments [10]. In this work, polyvinyl alcohol (PVA) microfibers were modified to achieve a slip-hardening behavior of the cement composite. Therefore, it is necessary to reduce the chemical bond and increase the physical bond between the fiber surface and the matrix. Considering that the process of oxygen plasma termination has a time-unstable character, ie., the modified wettability gradually returns to the reference values, but on the other hand the time-stable character of the physical modification, it is actually the ideal type of modification. The fiber has also been modified in hydrogen plasma, which on surfaces of some materials (diamond) induces hydrophobic behavior, which, along with mechanical modifications, could be ideal for these fibers.

\section{MATERIALS}

Polyvinylalcohol (PVA) microfibers made by Kuraray were chosen for modification using oxygen and hydrogen plasma. PVA fibers, unlike most other types of polymeric fibers, have good wettability, but the physical bond with the cement matrix is insufficient. The mechanical properties of the fibers used are shown in Table 1

Surface modifications by oxygen plasma were performed using Tesla VT 214 device (inductively stimulated plasma), those by hydrogen plasma were per- 


\begin{tabular}{|c|c|c|c|c|c|c|c|}
\hline Fibers & Company & Туре & $\begin{array}{l}\text { Length } \\
{[\mathrm{mm}]}\end{array}$ & $\begin{array}{l}\text { Diameter } \\
{[\mu \mathrm{m}]}\end{array}$ & $\begin{array}{l}\text { Tensile } \\
\text { strength [MPa] }\end{array}$ & $\begin{array}{l}\text { Modulus } \\
\text { of elasticity [GPa] }\end{array}$ & $\begin{array}{l}\text { Density } \\
{[\mathrm{g} / \mathrm{cm} 3]}\end{array}$ \\
\hline PVA & Kuraray & $\begin{array}{l}\text { REC } \\
15 \times 8\end{array}$ & 8 & 40 & 1560 & 40 & 1,3 \\
\hline
\end{tabular}

TABLE 1. Fiber properties.

formed in the ROTH \& RAU AK 400 (capacitance stimulated plasma). A radio frequency source of 100 $\mathrm{W}$ was used for the both instruments. The samples were placed in the chamber of the device. That was subsequently evacuated to pressure less than $22 \mathrm{~Pa}$. Subsequently, oxygen or hydrogen gas was applied into the chamber and the pressure increased to about $60 \mathrm{~Pa}$. Then the radiofrequency plasma generator was triggered for $30 \mathrm{~s}, 60 \mathrm{~s}, 120 \mathrm{~s}, 240 \mathrm{~s}$ or $480 \mathrm{~s}$. The temperature of the fibers in the chamber gradually increased during the plasma modification, reaching the temperature in the longest time around $50{ }^{\circ} \mathrm{C}$. Upon completion of the plasma modification, working gas was re-pumped from the chamber and subsequently aerated to atmospheric pressure. Based on the results of these measurements, fibers were selected for the test specimens with a modification time of 480 $\mathrm{s}$ in oxygen plasma and $480 \mathrm{~s}$ in hydrogen plasma. After the modification, the fibers were immediately placed into the sealed bags to prevent air exchange and unpacked just before production of the samples. Another fibers with a $480 \mathrm{~s}$ plasma oxygen treatment were stored in a laboratory environmental at $22 \pm 1$ ${ }^{\circ} \mathrm{C}$ and relative humidity $50 \pm 2 \%$ (Table 2).

\begin{tabular}{|l|l|l|l|l|}
\hline Designation & Fibers & $\begin{array}{l}\text { Modification } \\
\text { time }[\mathrm{s}]\end{array}$ & $\begin{array}{l}\text { Plasma } \\
\text { gas }\end{array}$ & Storage \\
\hline $\begin{array}{l}\text { PVA } \\
480 \mathrm{~s}\end{array}$ & PVA & 480 & oxygen & $\begin{array}{l}\text { Sealed } \\
\text { bags }\end{array}$ \\
\hline $\begin{array}{l}\text { PVA } \\
\text { h2 } 480 \mathrm{~s}\end{array}$ & PVA & 480 & hydrogen & $\begin{array}{l}\text { Sealed } \\
\text { bags }\end{array}$ \\
\hline $\begin{array}{l}\text { PVA } \\
480 \mathrm{~s} \text { old }\end{array}$ & PVA & 480 & oxygen & $\begin{array}{l}\text { Open } \\
\text { bags }\end{array}$ \\
\hline
\end{tabular}

TABLE 2. Fibers modification.

A total of 4 sets which each contains 6 samples were made. The dimensions of the test samples were $40 \times 40 \times 160 \mathrm{~mm}$. Portland cement CEM 42,5R (Radotin) and finely ground concrete recyclate were used to produce the test specimens. The composition of all test samples was identical, differing only in the modifications of the fiber surfaces (Table 3 .

\begin{tabular}{|l|l|l|l|}
\hline Designation & Cement $[\mathrm{g}]$ & Recyclate $[\mathrm{g}]$ & Water $[\mathrm{g}]$ \\
\hline PVA ref & 400 & 100 & 205 \\
PVA 480 s & 400 & 100 & 205 \\
PVA h2 480 s & 400 & 100 & 205 \\
PVA 480 s old & 400 & 100 & 205 \\
\hline Designation & $\mathrm{W} /(\mathrm{C}+\mathrm{R})$ & Fibers [\%] volume & Fibers $[\mathrm{g}]$ \\
\hline PVA ref & 0,41 & 2 & 7,32 \\
PVA 480 s & 0,41 & 2 & 7,32 \\
PVA h2 480 s & 0,41 & 2 & 7,32 \\
PVA 480 s old & 0,41 & 2 & 7,32 \\
\hline
\end{tabular}

TABLE 3. Composition of the samples.

\section{Experimental Methods And RESULTS}

All fibers were weighed by Kern with measuring accuracy $0.1 \mathrm{mg}$ before and after their plasma modification. The highest weight loss occurred in the case of fibers modified by oxygen plasma for $480 \mathrm{~s}$. Loss was equal to $0.58 \%$ of their original weight. This was caused by the bombardment of working gas. Based on the measured data, it can be concluded that the loss of mechanical properties of the fibers (reduction of the fiber cross-section) is almost negligible. The fiber surface was examined using the Merlin ZEISS electron microscope, which allows the observed object to be magnified up to 2,000,000 times. To observe objects under an electron microscope, the surface of the fiber needs to be conductive. To obtain the conductivity of the surface of the fibers, a thin layer of gold was sputtered on them. Sprinkling was carried out using a Quorum Q150R ES with an Au thickness of $5 \mathrm{~nm}$. Mechanical changes on fiber surfaces relative to reference fibers were observed by electron microscopy at plasma modification time $240 \mathrm{~s}$ and $480 \mathrm{~s}$ (Figure 1).

Fiber wettability was measured by an indirect method, similar to that called the Packed-cell. Because of the small fiber diameter, it was not possible to use direct fiber wettability measurement like for macrofibers. The amount of water on fibers after the fibers were dipped was measured. The fibers were placed in a small container with perforated bottom and lid. Subsequently, the fibers were compressed using lead weights. The whole of this system was weighed by Kern with accuracy $0.1 \mathrm{mg}$ and then immersed up to the water for 30 seconds. Then, the container was taken out of the water and weighed after 120 seconds. The container with lead weights was weighed as well. From the measured data, the percentage weight of the water in the container compared to the weight of the fibers was calculated in Figure 2,

Based on the measurement results, fibers modified by oxygen plasma for 480 seconds and those modified by hydrogen plasma for the same time were selected for the production of test specimens. After modification, the fibers were stored in sealed bags or in open bags for 5 days in a laboratory environment at $22 \pm 1^{\circ} \mathrm{C}$ and a relative humidity of $50 \pm 2 \%$. The samples were tested by bending test with a three-point configuration and under pressure at 28 days of age. Samples were loaded with a controlled displacement in a Heckert model FP100 hydraulic press at a constant rate of $0.4 \mathrm{~mm}$ per minute. The remaining parts of the test 


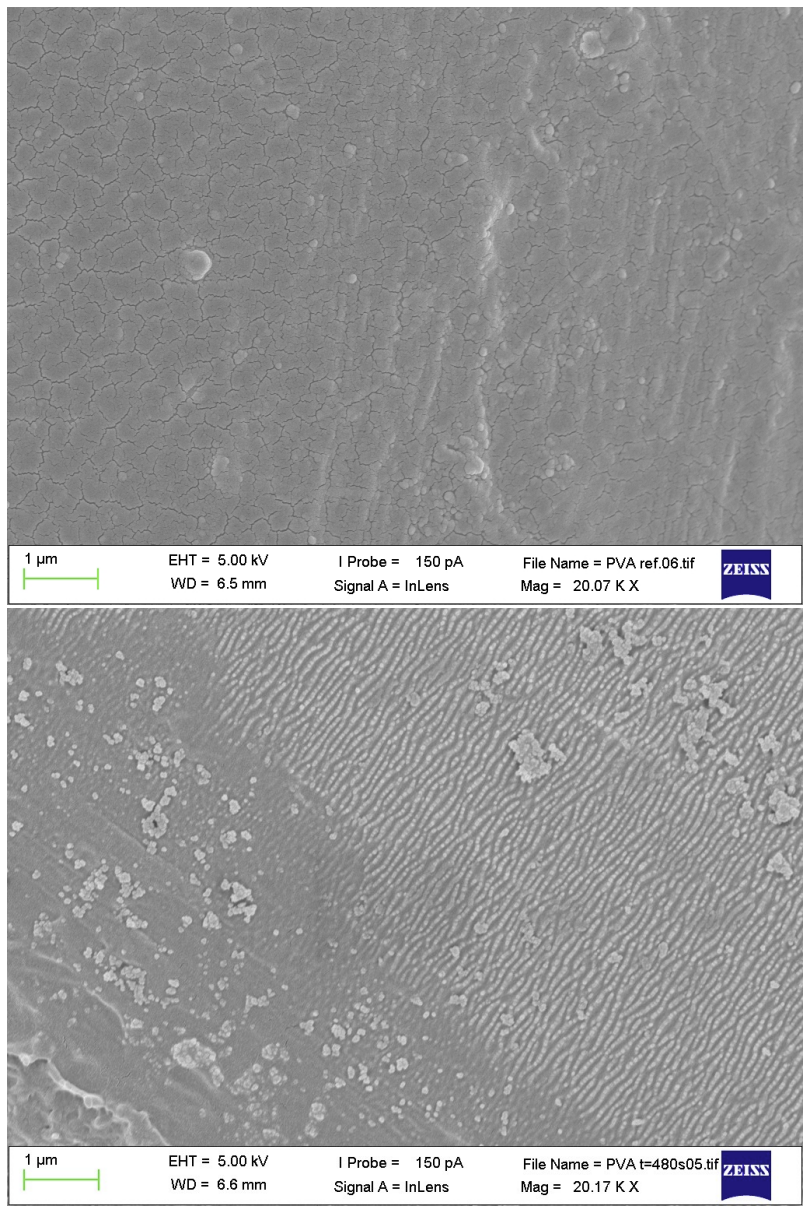

Figure 1. Comparison of reference (up) and $480 \mathrm{~s}$ modified (down) fibre surface by oxygen plasma.

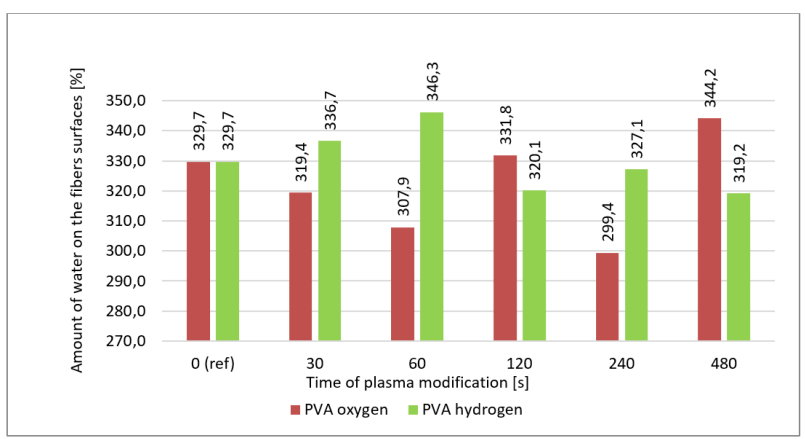

Figure 2. The weight of water between the fibers.

specimens were tested at pressure with loading speed of $0.8 \mathrm{~mm}$ per minute. Bending strength for samples with oxygen-modified fibers increased by 15 and $36 \%$, bending strength for samples which contains hydrogen plasma modified fibers decreased by approximately $20 \%$ in compare with reference samples (Figure 3). Compressive strength was reduced by approximately $5 \%$ for hydrogen-modified samples.

\section{Conclusion}

PVA fibers modified by hydrogen plasma for 480 seconds have been shown to have their more hydrophobic behavior due to the chemical effect of this modifica- tion. The mechanical effect of this modification, as with the oxygen plasma modification of these fibers, almost does not occur and the loss of bending strength after reaching the maximum is almost the same as for the reference fibers (Figure 4). For PVA fibers, it may be appropriate to use hydrogen plasma due to its hydrophobic chemical effect, but it is necessary to significantly increase the mechanical effect of the hydrogen plasma modification. Increase of the radiofrequency power or extension of the plasma modification time could increase the mechanical effect of modification.

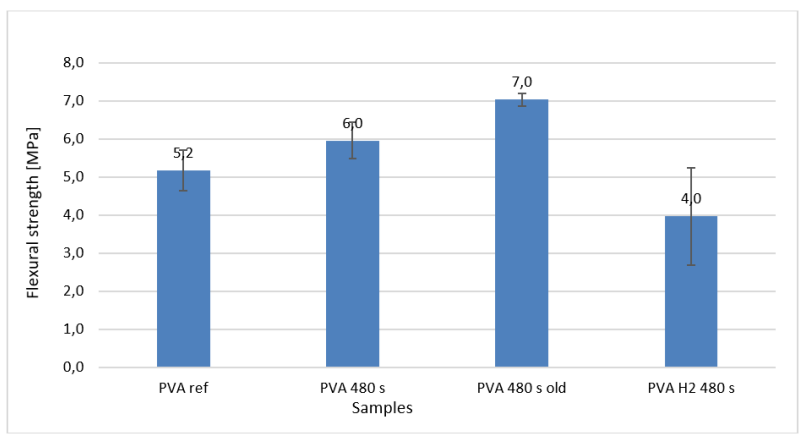

Figure 3. Comparison of Flexural strength.

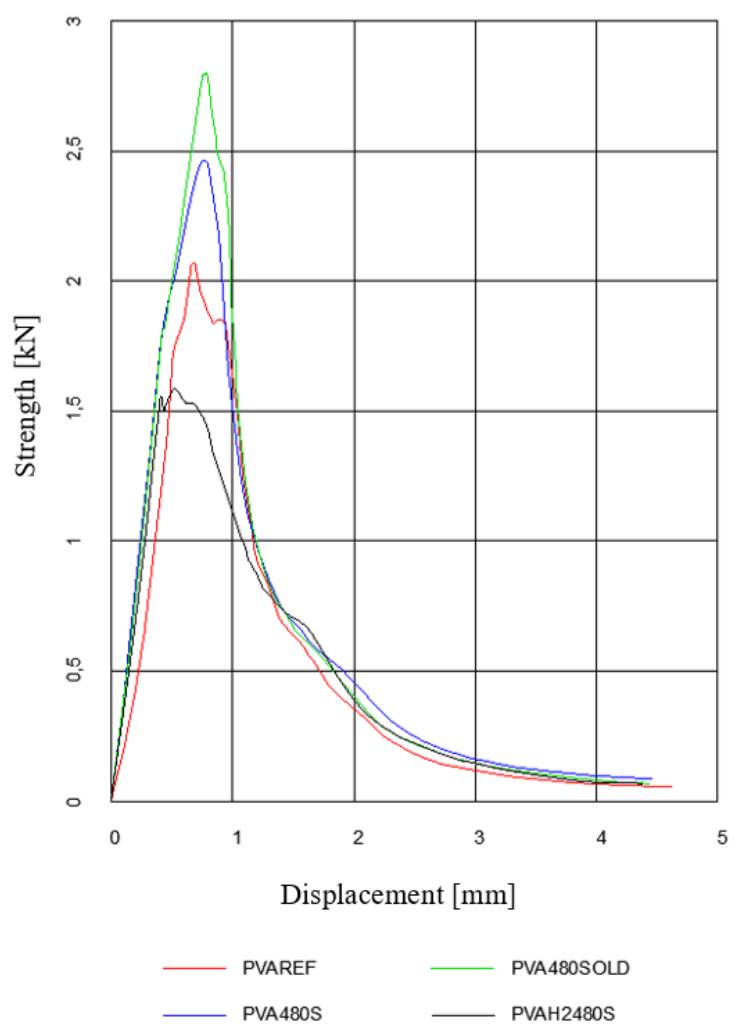

Figure 4. Force-displacement diagram of bending test.

\section{ACKNOWLEDGEMENTS}

This outcome was supported by the CTU in Prague under No. SGS16/201/OHK1/3T/11 and by the Ministry of Education, Youth and Sports within National Sustainability 
Programme I, project No. LO1605.

\section{REFERENCES}

[1] Z. Keršner. Křehkost a lomová mechanika cementových kompozitů., 2005. Brno. Habilitační práce. VUT v Brně.

[2] D. Bharathi. The history of fibre reinforcement. [online], 2015. [cit. 2017-10-31], https://www.linkedin.com/ pulse/history-fibre-reinforcement-bharathi-d.

[3] A. Bentur, S. Mindess. Fibre reinforced cementitus composites, 2007. 2nd ed., New York: Taylor, ISBN 978-020-3088-722.

[4] Rose, Margret. Definition plasma. [online], 2017. [cit. 2017-10-31],

http://whatis.techtarget.com/definition/plasma.

[5] S. R. Sabren. Cold Gas Plasma Surface Modification Optimize Plastics Bonding Adhesion. [online], 2012. [cit. 2017-10-31], http://www.adhesionbonding.com/2012/ 04/30/cold-gas-plasma-surface-modification optimize-plastics-bonding-adhesion/.

[6] D. Chrysostomou. Plasma surface modification for the biomedical industry., 2009. Presentation.

[7] J. Moosburger-Will, M. Bauer, F. Schubert, et al. Methyltrimethoxysilane plasma polymerization coating of carbon fiber surfaces. Surface and Coatings Technology pp. 223-230, 2017. [cit. 2018-01-06], DOI:10.1016/j.surfcoat.2017.01.017.
[8] L. Eung-seok, L. Choong-hyun, C. Yoon-Soo, et al. Effect of hydrogen plasma-mediated surface modification of carbon fibers on the mechanical properties of carbon-fiber-reinforced polyetherimide composites. Composites Part B: Engineering 2016. [cit. 2018-01-06], DOI:10.1016/j.compositesb.2016.10.088

[9] R. Pulíček. Optimalizace procesu hydrofilizace polypropylenového textilu pomocí DBD atmosférické plazmy, 2016. Liberec. Diplomová práce, Technická univerzita $\mathrm{v}$ Liberci.

[10] B. Barra, S. Santos, P. Bergo, et al. Residual sisal fibers treated by methane cold plasma discharge for potential application in cement based material. [online], 2015. [cit. 2018-01-06]. 